\title{
THE QUARREL
}

BETWEEN

\section{THE EARL OF MANCHESTER}

\section{OLIVER CROMWELL:}

AN EPISODE OF THE ENGLISH CIVIL WAR.

UNPUBLISHED DOCUMENTS RELATING THERETO,

COLLEOTED BY THE LATE JOHN BRUCE, F.S.A., \&C;

WITH FRAGMENTS OF

A HISTORICAL PREFACE BY MR. BRUCE,

ANNOTATED AND COMPLETED BY DAVID MASSON.

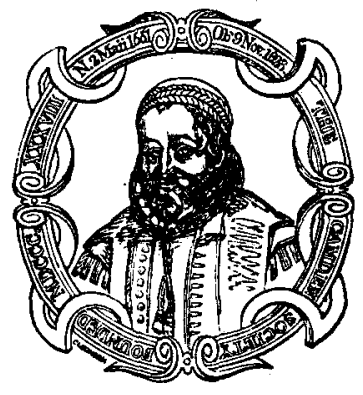

PRINTED FOR THE CAMDEN SOCIETY.

M.Dccc.LXXV. 
WESTMINSTER :

PRINTED BY NICHOLS AND SONS, 20̃, PARLIANENT STREET.

[NEW SERIES XII.] 


\title{
COUNCIL OF THE CAMDEN SOCIETY \\ FOR THE YEAR 1874-75.
}

\author{
President, \\ THE RIGHT HON. THE FARL OF VERULAM, F.R.G.S. \\ WILLIAM CHAPPELL, ESQ. F.S.A., Treasurer. \\ WILLIAM DURRANT COOPER, ESQ. F.S.A. \\ HENRY CHARLES COOTE, ESQ. F.S.A. \\ FRIEDERICK WILLIAM COSENS, ESQ. \\ JAMES GAIRDNER. ESQ. \\ SAMUEL RAWSON GARDINER, ESQ., Director. \\ ALFRED KINGSTON, ESQ., Secretary. \\ SIR JOHN MACLEAN, T.S.A. \\ FRISDERIC OUVRY, ESQ. V.P. S.A. \\ JAMES ORCHARD PHILLIPPS, ESQ. F.R.S. F.S.A. \\ IEDWARD RIMBAULT, LL.D. \\ REV. W. SPARROW SIMPSON, D.D. F.S.A. \\ JAMES SPEDDING, ESQ. \\ WIILLIAM JOHN THOMS, ESQ. F.S.A. \\ J. R. DANIEL-TYSSEN, ESQ.
}


The Council of the Camden Society desire it to be understood that they are not answerable for any opinions or observations that may appear in the Society's publications; the Editors of the several Works being alone responsible for the same. 


\section{INTRODUCTORY NOTE.}

Ar the death of Mr. Bruce, in October 1869, there was found among his papers a quantity of manuscript relating to the quarrel between the Earl of Manchester and Cromwell in the year 1644, and showing that he had been minutely studying that incident in the History of the English Civil War, and meant to make it the subject of some publication. The MSS. consisted of (1) Copies of previously unpublished documents recovered by $\mathrm{Mr}$. Bruce's research; (2) Fragments of a Historical Preface, in which Mr. Bruce meant to tell the whole story at some considerable length, by weaving the information from these documents into that otherwise accessible; and (3) Miscellaneous jottings towards the completion of this Preface, chiefly in the form of extracts from the Lords and Commons Journals, but with notes of dates and stray facts besides.

The documentary matter, as left by Mr. Bruce, and as put to press by the Council of the Camden Society for this volume, is partly from the Public Record Office, partly from the Manchester Family Papers at Kimbolton. From the Letter-Books of the Derby House Committee or Committee of Both Kingdoms, preserved in the Record Office, are the copies of the correspondence between that Committee and the Earl of Manchester from July to November 1644, occupying pp. 1-58 of the present volume; and from the Domestic State Papers in the Record Office is the document entitled Cromwell's Narrative (pp. 78-95). The remaining three documents, entitled Narrative of the Earl of Manchester's Campaign (pp. 59-70), Statement by an Opponent of Cromwell (pp. 71-77), and Notes of Evidence, \&c. (pp. 96-99), are from the Kimbolton Papers. The footnotes to the documents are by Mr. Bruce, except those signed. " G. C.," which are by Colonel Colomb.

The Council of the Camden Society having sent me the documents in their present printed form, together with the MS. fragments of Mr. Bruce's intended Historical Preface and the miscellaneous CAMD. SOC. 
MS. jottings he had left besides, I have had much pleasure, both from respect to Mr. Bruce's memory and from interest in the subject, in complying with their request that I would do what might be necessary or possible towards completing the Preface. The result has been as follows:-Every word of Mr. Bruce's Preface, so far as it had been written, has been religiously kept; and the completion has been endeavoured in the three forms of Notes, Insertions, and Continuation. The Notes (initialed where they are not Mr. Bruce's own) are (ew. The Insertions, always given within brackets, are either attempts to fill up gaps left in Mr. Bruce's manuscript, and which he meant to fill up at his leisure, or they are additions necessary for the coherence of the story at points where I could perceive that Mr. Bruce would almost certainly have made some such additions in revising what he had written. The Continuation was a more troublesome affair. Mr. Bruce had, unfortunately, broken off just as he was approaching the heart of his subject, and when he had begun a more minute style of narrative in preparation for what was coming. To have huddled up the sequel in a mere casual paragraph or two would have been to leave Mr. Bruce's design unintelligible. It would have done no manner of justice either to the documents he had collected or to the perception that had actuated him in collecting them and in writing his Preface so far-the perception, namely, of the significance of the quarrel between Manchester and Cromwell, and its involution with all that was most important in a whole important year of English history. I tried, therefore, to put myself in Mr. Bruce's place, and to finish his Preface on his own plan, by combining the material supplied by the documents with that to be found in Rushworth, Baillie, the Journals of the Lords and Commons, and other standard authorities. The extracts he had himself made from the Journals, with such hints as I could gather from his other MS. jottings, have been of use both in the Continuation and in the Insertions; and I have thought it right carefully to note every instance of help thus received from his own dead hand.

Edinburgh: February 1875.

David Masson. 


\section{CONTENTS.}

PAGE

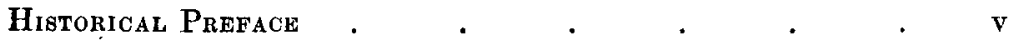
Documents : -

I. Correspondence between the Earl of Manchester And the Commitee of Both Kingdoms $\quad$. $\quad 1$

II. Narrative of the Earl of Manchester's Campatgn $\quad 59$

III. Statement by an Opponent of Cromwell . $\quad$. 71

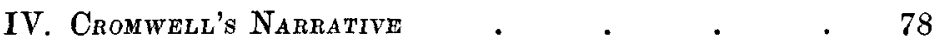

V. Notes of Evidence against the Earl of Manchester 96 


\section{ERRATA IN DOCUMENTS.}

Pp. 48, 49, 50, 52 : for the signature "W. Jhonston" in these pages, read "A. Jhonston." He was the Scottish Commissioner, Sir Archibald Johnston, of Warriston; and the mistake has arisen from the peculiar shape of " $\mathrm{A}$ " in the copy of his signature.

P. 60, the sentence should stop after "Yorke" in line 3, and the words from "In the aforesaid" to "Lincolne" should run into one sentence with the following words, "the sinister endes," \&c.

P. 61, line 7 from bottom, for "Montagne's" read "Montague's."

P. 63, last footnote, for "Rushwood " read "Rushworth."

P. 64, line 4, for "lefte on seconded" read "lefte onseconded ;" which is a Scottish form for "left unseconded." 